\title{
Evaluation of the Neonatal Pig As a Model for Infant Nutrition: Effects of Different Proportions of Casein and Whey Protein in Milk on Nitrogen Metabolism and Composition of Digesta in the Stomach
}

\author{
MICHAEL J. NEWPORT ${ }^{(33)}$ AND MICHAEL J. HENSCHEL \\ National Institute for Research in Dairying, Shinfield, Reading RG2 9AT, Berkshire, United Kingdom
}

\begin{abstract}
Summary
Neonatal pigs were evaluated as a model for protein metabolism of infants. Milks were given in which the protein (15 or 30 $\mathrm{g} /$ liter) was supplied by casein and whey in the proportions of 80:20 or 40:60. Severe or moderate restriction of feed intake was also compared. Whey-predominant milks reduced the concentration of urea $\mathbf{N}$ in blood plasma and the proportion of urea $\mathbf{N}$ in urinary total $N$. These effects are consistent with most previously reported data from infants, particularly those of low birth weight. The efficiency of $\mathbf{N}$ retention was improved at the higher concentration of dietary protein. Whey-predominant milks also reduced the amount of $\mathrm{N}$ retained in the stomach. The magnitude of some of these effects was influenced by the level of feed intake. Total $\mathrm{N}$ retention reflected protein intake but was not affected by protein source. $\mathrm{N}$ retention determined by a balance procedure exceeded that calculated from carcass analysis, but the effect of protein intake was similar from either procedure.
\end{abstract}

\section{Abbreviation}

DM, dry matter

Similarities in the digestive system of man and the pig suggest that results of studies on digestion and nutrition in the pig may be applicable to man (9). Some similarities in neonatal glucose metabolism have also been demonstrated (13). Other studies in neonatal pigs have assumed that results may be relevant, for example, in studies on protein nutrition $(28,23)$. However, no systematic comparisons of protein utilization have been made between the two species during the neonatal period. Such comparisons must inherently be rather superficial since ethical considerations limit the data on protein nutrition and digestion from infants to parameters of growth, nutrient retention, and analyses of blood.

Between species, there is considerable variation in the proportions of casein and whey proteins in the protein of the milk. Whey proteins account for about 20,50 , and $80 \%$ of the total protein in bovine (26), porcine (27), and human milks (16), respectively. The desire to "humanize" dried milk formulas for infants which were previously based on unmodified bovine milk gave rise to studies in which formulas containing predominantly casein or whey protein were compared in infants. At the time of these studies, it was believed that whey proteins contributed only $60 \%$ of the total protein in human milk (16). Although not all differences were statistically significant, low birth weight infants given formulas containing predominantly whey proteins did show improved $\mathrm{N}$ retention (2) and reduced concentrations of urea in plasma (24), suggesting a better utilization of the protein. Increasing the protein concentrations in the milk also reduced the efficiency of protein utilization (24). In term infants, plasma urea concentration was also reduced by a formula containing predominantly whey proteins (19), but a recent study detected no differences in the utilization of casein and whey proteins (17). As it was desired to test the validity of the neonatal pig as a model for infant nutrition, milks containing either casein or whey as the predominant protein have been compared at two levels of protein intake in neonatal pigs. In view of the substantial proportion of whey proteins in sow's milk, enriching a milk substitute with whey proteins could also have important implications in the rearing of early weaned pigs.

These studies have also been extended to compare gastric digestion and emptying following slaughter under standardized conditions. In vitro studies in our laboratory (unpublished) showed that the coagulation time following the addition of bovine chymosin was inversely related to the casein content of the milks. Therefore, an increase in the proportion of whey protein might increase the rate of gastric emptying. Previous work has shown that whole cow's milk quickly coagulated in the stomach of the 4-week-old pig, followed by rapid draining of the whey (6). Also, the amount of dry matter in the stomach was usually decreased when milk was replaced by noncoagulating proteins derived from soybeans or fish (21). Knowledge of factors affecting gastric emptying would be very important clinically in determining the most appropriate type of formula and the method of feeding, particularly in those low birth weight infants where intragastric feeding is necessary. This category is becoming more important with improvements in survival rates of premature infants.

As infant growth rates are much lower than those of suckled pigs, the feed intakes of the pigs in the first experiment were heavily restricted to give low growth rates, conditions under which the data may be more relevant to the human situation. In a second experiment, the feeding level was more generous, but rates of growth were still below those expected for suckling pigs of a similar age (1).

\section{MATERIALS AND METHODS}

Four liquid diets were prepared based on cow's milk solids with casein: whey protein ratios of $80: 20$ or $40: 60$ and with crude protein (nitrogen $(\times 6.38)$ contents of 15 or $30 \mathrm{~g} /$ liter (Table 1 ). 
All diets contained spray-dried skim milk prepared by a mild heat procedure to avoid denaturing the whey proteins (Volac Ltd, Royston, Hertfordshire). The ultrafiltered skim milk, concentrated $\times 2$, was prepared at the Institute. Spray-dried whey protein concentrate (Lactein 70) and lactose (Serolac BP) were obtained from the Milk Marketing Board, Thames Ditton, Surrey, and de-odorized soybean oil was from Croda Oils Ltd, London. Diets were prepared twice weekly by homogenizing all ingredients in water at a pressure of $176 \mathrm{~kg} / \mathrm{cm}^{2}$ with glycerol monostearate as an emulsifier, and pasteurizing at $72^{\circ} \mathrm{C}$ for 17 sec. All diets contained 70 and $35 \mathrm{~g} /$ liter of carbohydrate and lipid, respectively. Analysis for noncasein $N(25)$ indicated an undernatured whey protein content of 148 and $777 \mathrm{~g} / \mathrm{kg} \mathrm{N}$ in the dried skim milk and whey protein concentrate, respectively. Mineral and vitamin supplements (Table 1) and, as a preservative, formalin solution $(0.5 \mathrm{ml} /$ liter $)$ were added daily before offering the diets to the pigs.

Littermate 2-day-old pigs were allocated to the four diets, equalizing initial weight and numbers of either sex between diets. The pigs were fed at hourly intervals using an automatic feeder $(4,5)$ for 14 days. There were 12 pigs/diet in two separate experiments in which they were given 250 and $375 \mathrm{ml} / \mathrm{kg}$ live

Table 1. Composition of the diets (per liter)*

\begin{tabular}{lrrrr}
\hline \multicolumn{1}{c}{ Diet } & A & B & C & D \\
\hline Casein:whey protein ratio & & $80: 20$ & & \multicolumn{2}{c}{$40: 60$} \\
Protein level $(\mathrm{g})$ & 15 & 30 & 15 & 30 \\
Ultrafiltered skim milk concentrated $\times 2$ & & 188 & & 94
\end{tabular}

$$
\text { (ml) }
$$

Spray-dried skim milk (g)

Spray-dried whey protein concentrate $(\mathrm{g})$

Lactose $(\mathrm{g})$

Soybean oil (g)

$\begin{array}{llll}45.0 & 45.0 & 22.5 & 22.5\end{array}$

Glycerol monostearate (g)

$9.8 \quad 19.6$

$\begin{array}{llll}49.5 & 47.7 & 59.0 & 56.1\end{array}$

$\begin{array}{llll}35.0 & 35.0 & 35.0 & 35.0\end{array}$

$\begin{array}{llll}1.0 & 1.0 & 1.0 & 1.0\end{array}$

* All diets were supplemented with vitamins (per liter of diet): retinol, $90 \mu \mathrm{g}$; cholecalciferol, $0.4 \mu \mathrm{g} ; \alpha$-tocopherol, $1.23 \mathrm{mg}$; menaphthone, 84 $\mu \mathrm{g}$; thiamin, $2.23 \mathrm{mg}$; riboflavin, $3.75 \mathrm{mg}$; pyridoxin, $3.7 \mathrm{mg}$; nicotinic acid, $30.5 \mathrm{mg}$; pantothenic acid, $1.63 \mathrm{mg}$; cyanocobalamin, $25 \mu \mathrm{g}$; biotin, $75 \mu \mathrm{g}$; pteroylmonoglutamic acid, $825 \mu \mathrm{g}$; choline, $1.25 \mathrm{~g}$. Minera supplements added to diets $\mathrm{A}$ and $\mathrm{B}$ supplied (mg/liter of diet): $\mathrm{Cu}, 0.9$; $\mathrm{Fe}, 2.0 ; \mathrm{Zn}, 3.1$; and to diets $\mathrm{C}$ and $\mathrm{D}: \mathrm{Ca}, 267 ; \mathrm{K}, 372 ; \mathrm{Na}, 122 ; \mathrm{Mg}$, 27.2; $\mathrm{P}, 214 ; \mathrm{Cu}, 1.3 ; \mathrm{Fe}, 3.0 ; \mathrm{Zn}, 4.7$. Calculated from analyses of ingredients, diets contained (mg/liter): $\mathrm{Ca}, 600 ; \mathrm{P}, 465 ; \mathrm{Na}, 255 ; \mathrm{K}, 765$ (diets A and C); Ca, 890; P, 645, Na, 285; K, 815 (diets B and D). Gross energy (kJ/liter): 2809 (diets A and C); 3085 (diets B and D). weight/day. $\mathrm{N}$ retention was estimated during two 4-day balance periods; the amount of feces was negligible and was not analyzed (3).

At 16 days of age, the pigs were killed by an intracardiac injection of sodium pentobarbitone $l \mathrm{~h}$ after a feed. Blood was withdrawn from the heart into heparinized tubes; plasma was separated by centrifugation and stored at $-20^{\circ} \mathrm{C}$. The stomach was removed, the digesta were emptied; $\mathrm{pH}$ was measured using a $\mathrm{pH}$ meter, and stored at $-20^{\circ} \mathrm{C}$. Carcasses from 6 pigs/diet given the higher level of intake were stored at $-20^{\circ} \mathrm{C}$ after removing the remainder of the alimentary tract, minced frozen, and samples were freeze-dried and ground prior to analysis.

DM was determined in the milk-protein ingredients, digesta, and carcasses by drying at $105^{\circ} \mathrm{C}$ for $17 \mathrm{~h}$ and $\mathrm{N}$ by the Kjeldahl procedure with analysis of liberated ammonia using a Technicon Autoanalyzer (Technicon Instruments Co Ltd, Chertsey, Surrey). Ingredients were also analyzed for total lipid (14), phosphorus (7), and calcium, sodium, and potassium by atomic absorption spectroscopy. Noncasein $\mathrm{N}$ was estimated by the method of Rowland (25) and nonprotein $\mathrm{N}$ as the $\mathrm{N}$ in the filtrate following the addition of an equal volume of trichloroacetic acid (100 g/ liter). Urea $\mathrm{N}$ was analyzed in urine and blood plasma by an automated technique based on the method of Marsh et al. (18).

\section{RESULTS}

Performance was clearly improved by the higher level of intake and protein concentration in the diet but the proportions of casein or whey proteins had no effect (Table 2). At the lower level of intake, although there was no mortality, growth rates were extremely poor in four pigs even though most of the ration was consumed. This gave abnormally high ratios of feed:gain. Data on these four pigs were excluded from the analyses.

$N$ metabolism. Age had no significant effect $(P>0.05)$ on $\mathrm{N}$ retention in this comparatively short experiment. Therefore only data from one collection period are presented (Table 3). Although differences in the proportion of $\mathrm{N}$ retained were not generally significant, some increase was found in the milks containing predominantly whey protein and also in those of higher protein content. At the higher level of feeding, weight gain/g $\mathrm{N}$ retained was greater at the lower level of protein in the diet. The proportion of urea in the total $\mathrm{N}$ excreted in the urine was consistently lower in the whey-predominant milks; level of protein in the milk had no effect. The whey-predominant milks also consistently reduced the plasma urea $\mathrm{N}$ concentrations, but the difference was only statistically significant at the higher level of intake (Table 3).

Table 2. Growth of pigs from 2-16 days of age given 250 or $375 \mathrm{ml} / \mathrm{kg} /$ day of milk substitutes with ratios of casein:whey protein of 80:20 or $40: 60$ and crude protein $(N \times 6.25)$ contents of 15 or $30 \mathrm{~g} /$ liter (mean values for 12 pigs/diet)

\begin{tabular}{|c|c|c|c|c|c|c|c|c|}
\hline \multirow{2}{*}{$\begin{array}{c}\text { Feed intake } \\
(\mathrm{ml} / \mathrm{kg} \text { live } \mathrm{wt} / \text { day })\end{array}$} & & \multicolumn{4}{|c|}{$\begin{array}{c}\text { Casein: } \\
\text { whey ratio at } \\
\text { protein level }(\mathrm{g} / \mathrm{liter})\end{array}$} & \multirow[b]{2}{*}{ SEM $^{*}$} & \multicolumn{2}{|c|}{ Statistical significance $\dagger$} \\
\hline & & 15 & 30 & 15 & 30 & & $\begin{array}{c}\text { Casein: } \\
\text { whey }\end{array}$ & $\begin{array}{c}\text { Protein } \\
\text { level }\end{array}$ \\
\hline \multirow[t]{4}{*}{250} & Energy intake $(\mathrm{kJ} / \mathrm{kg} /$ day $)$ & 702 & 773 & 702 & 773 & & & \\
\hline & Live wt gain $(\mathrm{kg})$ & 0.40 & 0.64 & 0.39 & 0.61 & 0.037 & NS & $a$ \\
\hline & Feed:gaint & 12.90 & 9.11 & 14.39 & 9.94 & 0.662 & NS & $a$ \\
\hline & Poor growth $\ddagger$ & 2 & 0 & 1 & 1 & & & \\
\hline \multirow[t]{4}{*}{375} & Energy intake $(\mathrm{kJ} / \mathrm{kg} /$ day $)$ & 1053 & 1158 & 1053 & 1158 & & & \\
\hline & Live wt gain $(\mathrm{kg})$ & 0.83 & 1.21 & 0.85 & 1.46 & 0.076 & NS & $a$ \\
\hline & Feed:gain & 11.89 & 9.08 & 12.96 & 7.77 & 0.800 & NS & $a$ \\
\hline & Mortality & 0 & 1 & 2 & 0 & & & \\
\hline
\end{tabular}

* For $250 \mathrm{ml} / \mathrm{kg}, 29 \mathrm{df}$; for $375 \mathrm{ml} / \mathrm{kg}, 30 \mathrm{df}$.

$\dagger^{*}$ NS, not significant. ${ }^{a} P<0.001$.

$\uparrow \mathrm{ml}$ milk consumed/kg gain.

$\ddagger$ Number of pigs excluded from analyses. There was no mortality. 
Table 3. Plasma urea $N$ in 16 -dav old pigs, and $N$ retention and urea excretion at 7 days of age when given $250 \mathrm{or} 375 \mathrm{ml} / \mathrm{kg} /$ day of milk substitutes with ratios of casein:whev protein of $80: 20$ or $40: 60$ and crude protein $(N \times 6.25)$ contents of 15 or $30 \mathrm{~g} /$ liter (mean values for $12 \mathrm{pigs} /$ diet)

\begin{tabular}{|c|c|c|c|c|c|c|c|c|}
\hline \multirow{3}{*}{$\begin{array}{c}\text { Feed intake } \\
(\mathrm{ml} / \mathrm{kg} \text { live } \mathrm{wt} / \text { day })\end{array}$} & & \multicolumn{4}{|c|}{$\begin{array}{l}\text { Casein:whey ratio at } \\
\text { protein level }(\mathrm{g} / \mathrm{liter})\end{array}$} & \multirow{3}{*}{$\begin{array}{l}\text { SEM } \\
(33 d f)\end{array}$} & \multicolumn{2}{|c|}{ Statistical significance* } \\
\hline & & \multicolumn{2}{|c|}{$80: 20$} & \multicolumn{2}{|c|}{$40: 60$} & & \multirow{2}{*}{$\begin{array}{l}\text { Casein: } \\
\text { whey }\end{array}$} & \multirow{2}{*}{$\begin{array}{l}\text { Protein } \\
\text { level }\end{array}$} \\
\hline & & 15 & 30 & 15 & 30 & & & \\
\hline \multirow[t]{11}{*}{250} & $\begin{array}{l}\text { Energy intake } \\
(\mathrm{kJ} / \mathrm{kg} / \text { day })\end{array}$ & 702 & 773 & 702 & 773 & & & \\
\hline & $\begin{array}{l}\text { Plasma urea N } \\
\qquad(\mathrm{mg} / 100 \mathrm{ml})\end{array}$ & 2.11 & 4.02 & 1.73 & 2.75 & 0.548 & NS & $a$ \\
\hline & Nitrogen $(N)$ & & & & & & & \\
\hline & Intake (mg/day) & 902 & 1512 & 891 & 1592 & 97.9 & NS & c \\
\hline & Urine (mg/day) & 173 & 226 & 136 & 179 & 48.1 & NS & $a$ \\
\hline & $\begin{array}{l}\text { Retention (mg/ } \\
\text { day) }\end{array}$ & 729 & 1286 & 755 & 1413 & 104.3 & NS & c \\
\hline & $\begin{array}{l}\text { Retention (\% of } \\
\text { intake) }\end{array}$ & 81.5 & 83.8 & 84.3 & 88.0 & 1.95 & NS & NS \\
\hline & Growth (g/day) & 58 & 67 & 43 & 93 & 20.7 & NS & b \\
\hline & $\begin{array}{c}\text { Growth }(\mathrm{g}) / \mathrm{N} \text { re- } \\
\text { tained }(\mathrm{g})\end{array}$ & 83.6 & 50.3 & 63.8 & 68.5 & 11.31 & NS & NS \\
\hline & $\begin{array}{l}\text { Urea } \mathrm{N} \text { in urine } \\
\qquad(\mathrm{mg} / \text { day })\end{array}$ & 96 & 143 & 46 & 84 & 30.0 & $c$ & $b$ \\
\hline & $\begin{array}{l}\text { Urea N (\% total } \\
\mathrm{N})\end{array}$ & 55.2 & 62.6 & 33.8 & 46.9 & 5.06 & $b$ & NS \\
\hline \multirow[t]{10}{*}{375} & $\begin{array}{l}\text { Energy intake } \\
\qquad(\mathrm{kJ} / \mathrm{kg} / \text { day })\end{array}$ & 1053 & 1158 & 1053 & 1158 & & & \\
\hline & $\begin{array}{l}\text { Plasma urea } \mathrm{N} \\
\quad(\mathrm{mg} / 100 \mathrm{ml}) \\
\text { Nitrogen }(\mathrm{N})\end{array}$ & 2.67 & 2.47 & 1.70 & 2.26 & 0.204 & $b$ & NS \\
\hline & Intake (mg/day) & 1839 & 3219 & 1971 & 3468 & 163.4 & $a$ & $c$ \\
\hline & Urine (mg/day) & 253 & 309 & 273 & 328 & 42.4 & NS & $a$ \\
\hline & $\begin{array}{l}\text { Retention (mg/ } \\
\text { day) }\end{array}$ & 1586 & 2910 & 1698 & 3140 & 171.9 & NS & c \\
\hline & $\begin{array}{l}\text { Retention (\% of } \\
\text { intake) }\end{array}$ & 86.2 & 90.1 & 86.5 & 90.6 & 0.95 & NS & $c$ \\
\hline & Growth (g/day) & 75 & 83 & 58 & 92 & 14.8 & NS & $a$ \\
\hline & $\begin{array}{c}\text { Growth }(\mathrm{g}) / \mathrm{N} \text { re- } \\
\text { tained }(\mathrm{g})\end{array}$ & 46.3 & 28.7 & 34.0 & 30.1 & 3.44 & NS & b \\
\hline & $\begin{array}{c}\text { Urea } N \text { in urine } \\
(\mathrm{mg} / \text { day })\end{array}$ & 111 & 135 & 71 & 67 & 36.2 & $b$ & NS \\
\hline & $\begin{array}{l}\text { Urea N (\% total } \\
\mathrm{N})\end{array}$ & 41.0 & 41.0 & 26.7 & 24.1 & 2.47 & c & NS \\
\hline
\end{tabular}

*NS, not significant. "P $<0.05, " P<0.01, " P<0.001$.

$\mathrm{N}$ retention determined by the balance technique was compared with carcass analysis (Table 4 ). The amount of $\mathrm{N}$ retained in the carcass was calculated from analysis at slaughter, minus the initial amount at 2 days calculated from Elsley (12). The amount of $\mathrm{N}$ retained during the two 4-day balance periods was extrapolated over the whole experiment. $\mathrm{N}$ retention determined by balance exceeded that based on carcass analysis. Pigs given the higher protein intake had a greater $\mathrm{N}$ content in the carcass, accompanied by lower DM and lipid contents (Table 5). The higher protein intake increased total $N$ retention $(P<0.001)$ but the proportions of casein and whey proteins had no effect $(P>$ $0.05)$.

Digestion in the stomach. There were no clear effects on the amount or composition of digesta in the stomach due to the level of feed intake (Table 6). Whey proteins had no effect on the amount of digesta, but there was a reduction when the higher protein milk was given at the higher level of intake. Reductions in the $\mathrm{pH}$ of the digesta of the whey-predominant milks and increases at the higher level of protein in the milk were consistent, though not statistically significant. Similar reductions with the whey-predominant milks were also found in the DM content in, and total DM and $\mathrm{N}$ of, the digesta. Some of these differences
Table 4. Total $N$ retention (g) calculated by balance or carcass analvsis of pigs from 2-16 days of age given $375 \mathrm{ml} / \mathrm{kg} /$ day of milk substitutes with ratios of casein: whey protein of $80: 20$ or 40:60 and crude protein $(N \times 6.25)$ contents of 15 or $30 \mathrm{~g} /$ liter (mean values for 6 pigs/diet)

\begin{tabular}{|c|c|c|c|c|c|c|c|}
\hline & \multicolumn{4}{|c|}{$\begin{array}{l}\text { Casein:whey ratio at } \\
\text { protein level (g/liter) }\end{array}$} & \multirow{3}{*}{$\begin{array}{l}\text { SEM } \\
(15 d f)\end{array}$} & \multicolumn{2}{|c|}{ Statistical significance* } \\
\hline & \multicolumn{2}{|c|}{$80: 20$} & \multicolumn{2}{|c|}{$40: 60$} & & \multirow{2}{*}{$\begin{array}{c}\text { Casein: } \\
\text { whey }\end{array}$} & \multirow{2}{*}{$\begin{array}{l}\text { Protein } \\
\text { level }\end{array}$} \\
\hline & 15 & 30 & 15 & 30 & & & \\
\hline Bala & 25.6 & 46.6 & 26.2 & 49.1 & 1.30 & NS & a \\
\hline Carcass & 27.1 & 42.9 & 22.8 & 40.7 & 2.96 & NS & a \\
\hline Balance:carcass & 0.96 & 1.16 & 1.35 & 1.25 & 0.117 & NS & NS \\
\hline
\end{tabular}

* NS, not significant. " $P<0.001$.

were statistically significant. The amount of $\mathrm{N}$ also reflected the protein content of the milks. At the higher level of intake, the proportion of nonprotein $\mathrm{N}$ in the total $\mathrm{N}$ was increased in the whey-predominant milk and reduced by milks having the higher protein concentrations. 
Table 5. Carcass composition of 16-day-old pigs given $375 \mathrm{ml} / \mathrm{kg} /$ day of milk substitutes with ratios of casein:whey protein of $80: 20$ or $40: 60$ and crude protein $(N \times 6.25)$ contents of 15 or $30 \mathrm{~g} /$ liter (mean values for 6 pigs/diet)

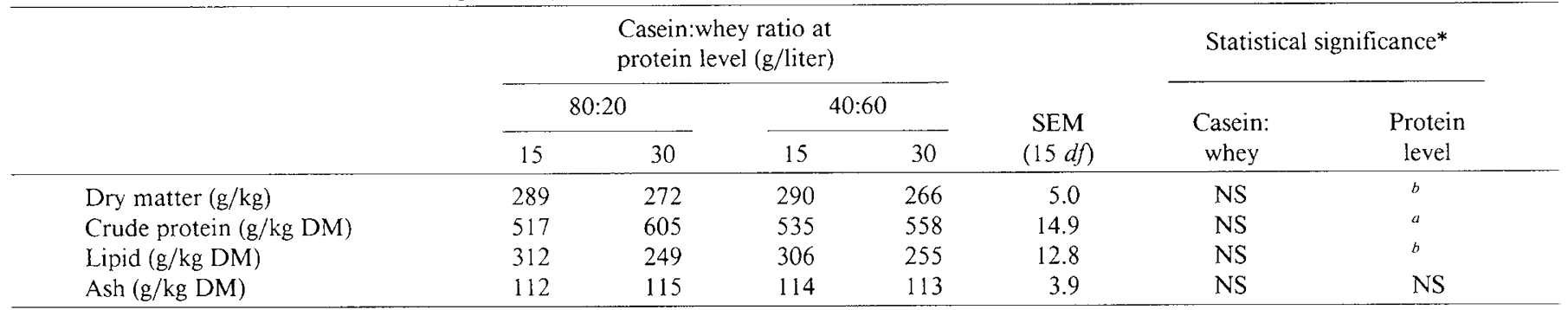

* NS, not significant. ${ }^{a} P<0.01,{ }^{b} P<0.001$.

Table 6. Amount, pH, and composition of digesta in the stomach of 16-day-old pigs given $250 \mathrm{or} 375 \mathrm{ml} / \mathrm{kg} /$ day of milk substitutes with ratios of casein:whey protein of $80: 20$ or $40: 60$ and crude protein $(N \times 6.25)$ contents of 15 or $30 \mathrm{~g} /$ liter (mean values for 12 pigs/treatment)

\begin{tabular}{|c|c|c|c|c|c|c|c|c|}
\hline \multirow{3}{*}{$\begin{array}{c}\text { Feed intake } \\
(\mathrm{ml} / \mathrm{kg} \text { live } \mathrm{wt} / \text { day })\end{array}$} & & \multicolumn{4}{|c|}{$\begin{array}{c}\text { Casein: } \\
\text { whey ratio at } \\
\text { protein level }(\mathrm{g} / \mathrm{liter})\end{array}$} & \multirow{3}{*}{$\begin{array}{l}\text { SEM } \\
(33 d f)\end{array}$} & \multicolumn{2}{|c|}{ Statistical significance* } \\
\hline & & \multicolumn{2}{|c|}{$80: 20$} & \multicolumn{2}{|c|}{$40: 60$} & & \multirow{2}{*}{$\begin{array}{l}\text { Casein: } \\
\text { whey }\end{array}$} & \multirow{2}{*}{$\begin{array}{c}\text { Protein } \\
\text { level }\end{array}$} \\
\hline & & 15 & 30 & 15 & 30 & & & \\
\hline \multirow[t]{7}{*}{250} & Stomach digesta & & & & & & & \\
\hline & Wt $(g)$ & 34.7 & 38.0 & 38.2 & 28.7 & 15.26 & NS & NS \\
\hline & $\mathrm{pH}$ & 3.01 & 3.48 & 2.91 & 2.90 & 0.269 & NS & NS \\
\hline & Dry matter $(\mathrm{g} / \mathrm{kg})$ & 157.4 & 168.2 & 123.5 & 105.2 & 12.02 & c & NS \\
\hline & Total DM (g) & 5.89 & 6.24 & 5.66 & 3.99 & 1.270 & NS & NS \\
\hline & Total N (mg) & 146 & 202 & 96 & 200 & 42.6 & NS & NS \\
\hline & Nonprotein $N(\mathrm{~g} / \mathrm{kg}$ total $\mathrm{N})$ & 93 & 125 & 154 & 63 & 43.5 & NS & NS \\
\hline \multirow[t]{7}{*}{375} & Stomach digesta & & & & & & & \\
\hline & $\mathrm{Wt}(\mathrm{g})$ & 47.6 & 38.9 & 46.9 & 33.0 & 5.47 & NS & $a$ \\
\hline & pH & 2.82 & 2.92 & 2.63 & 2.71 & 0.247 & NS & NS \\
\hline & Dry matter $(\mathrm{g} / \mathrm{kg})$ & 143.5 & 130.0 & 121.5 & 114.7 & 9.22 & NS & NS \\
\hline & Total DM $(\mathrm{g})$ & 8.10 & 5.69 & 6.12 & 4.43 & 1.115 & NS & NS \\
\hline & Total N (mg) & 201 & 507 & 102 & 134 & 71.7 & $b$ & $a$ \\
\hline & Nonprotein $\mathrm{N}(\mathrm{g} / \mathrm{kg}$ total $\mathrm{N})$ & 112 & 82 & 206 & 135 & 13.5 & $c$ & $c$ \\
\hline
\end{tabular}

* NS, not significant. ${ }^{a} P<0.01,{ }^{b} P<0.01,{ }^{c} P<0.001$.

\section{DISCUSSION}

The proportion of casein to whey protein in the milk did not affect the performance of the pigs, and neither have any effects on growth been found in infants except during early stages of a study (2). The performance of the pigs reflected the fact that a protein level in the diet of $15 \mathrm{~g} /$ liter, although adequate for infants (8), is below the requirement for pigs of this age. The level of $30 \mathrm{~g}$ crude protein/liter in these diets is close to the requirement of the pig (20). These differences in protein requirements are reflected in the milk composition of the two species (15). Four pigs, fed at the lower level of intake, were excluded from the analysis as a combination of poor growth but normal feed intake gave ratios of feed:gain exceeding by twice other values within a dietary group. However, the inclusion of these values did produce a statistically significant $(P<0.05)$ worsening of the ratio of feed:gain for whey-predominant milks.

The efficiency of $\mathrm{N}$ retention showed some improvement with the whey protein-predominant milks, but as in the studies of infants (2) differences were not statistically significant. The proportion of $\mathrm{N}$ excreted as urea was increased, and here differences were statistically significant in both the infant and baby pig. The efficiency of digestion and retention of $\mathrm{N}$ is greater in the pig (20) compared with the human infant (30), presumably reflecting its greater potential for growth.

Although the efficiency of $\mathrm{N}$ retention will normally be inversely related to intake (4), the present results show an opposite, but small, effect. Methodological error could account for this discrepancy as it is well known that the balance procedure may overestimate $\mathrm{N}$ retention due to spillage of feed and incomplete collection of excreta (31). These errors would be increased with diets of higher protein content, and could also explain the greater $\mathrm{N}$ retentions determined by the balance procedure compared with carcass analysis in the present experiment (Table 4). However, the balance technique as used in the present experiment appears to be satisfactory for comparative purposes. The lower protein content and increased fat content of pigs receiving the low protein diet is indicative of protein-deficient diets $(20,22)$.

The concentrations of urea in the blood plasma were reduced by the whey-predominant milks in the present experiment (Table 3). Similar trends were found in infant studies $(19,24)$, but Jarvenpaa et al. (17) found no differences between casein and whey proteins. These concentrations of urea were much lower than those found in suckling pigs (10) or in the infant studies, and indicate the higher efficiency of protein utilization and also that protein intakes were still below the requirement for optimum growth in the pig even at the higher levels of intake. The increase in plasma urea $\mathrm{N}$ at the higher protein level in the milks given at $250 \mathrm{ml} / \mathrm{kg} /$ day suggests that energy intake may be limiting protein utilization. This would be supported by the absence of any effect of dietary protein level on plasma urea at the higher level of intake.

The absence of a statistically significant effect of protein source on the amount of digesta or total DM remaining in the stomach was surprising in view of the slower coagulation rates in vitro for milk with predominantly whey protein (unpublished results). 
However, the absence of an effect could have been due to feed intakes in this experiment being below those of suckling pigs of a similar age both in dry matter content (11) and amount (1).

Although there was no effect on the amount of digesta or its total DM, the whey-predominant milks tended to produce digesta of lower $\mathrm{pH}$ and dry matter content, indicating a lower buffering capacity and poorer coagulation. At the higher level of intake, this type of milk reduced the $\mathrm{N}$ content of the digesta. Thus, gastric emptying rate of protein, if not of total digesta, may have been increased by whey proteins. The increased proportion of nonprotein $\mathrm{N}$ also indicated greater proteolysis. There have been no comparisons reported with different ratios of casein:whey protein of gastric emptying in infants, although Schreiner et al. (29) did report a lower incidence of lactobezoars in infants when a maternity unit discontinued the use of caseinpredominant formulas in favor of a formula containing predominantly whey protein.

Further work is needed to elucidate the level of feed intake or the frequency of feeding at which the proportion of casein or whey protein will influence coagulation in the stomach with its implications for gastric emptying. The present experiments clearly show that there is little effect under conditions of low intake and frequent feeding.

In the present study with neonatal pigs, we have found that a milk with protein mainly supplied by whey proteins did reduce plasma urea levels and proportion of urea in urinary $\mathrm{N}$, and improve $\mathrm{N}$ retention, thus suggesting that under some conditions the pig may be a useful model for protein utilization in the infant. One difficulty in reaching such a conclusion is the variability of the data from the clinical studies and their failure to establish statistical differences. In addition, the plasma urea $\mathrm{N}$ levels in the present experiment with pigs were about 5 -fold less than normally found in suckling pigs (10) or infants (24), indicating very efficient use of dietary protein. Differences between types of protein might be greater under conditions of less efficient protein utilization, for example if the feed intake of the pigs was increased. In this experiment, pigs were fed at hourly intervals, simulating the natural suckling frequency on the sow (1). Less frequent feeding would be closer to the human situation and may decrease the efficiency of protein utilization, although no evidence for this was found in earlier studies on neonatal pigs (4).

Applying the standard techniques of dairy chemistry developed for analysis of bovine milk showed that about $60 \%$ of the protein in human milk occurs as whey proteins. Modification of these procedures shows that whey proteins comprise about $80 \%$ of the total protein (16). The composition of current humanized infant formulas is based on the older analyses; therefore, an increase in whey protein content may be desirable in the attempt to approach the composition of human milk in a formula. Further experiments in neonatal pigs will be made to make a more detailed study of the effect of higher proportions, or sole use, of whey protein in a milk formula.

\section{REFERENCES AND NOTES}

1. Barber RS, Braude R, Mitchell KG 1955 Studies on milk production of Large White pigs. J Agric Sci Camb 46:97

2. Berger HM, Scott PH, Kenward C, Scott P, Wharton BA 1979 Curd and whey proteins in the nutrition of low birthweight babies. Arch Dis Child 54:98

3. Braude R, Keal HD, Newport MJ 1976 Artificial rearing of pigs. 5. The effect of different proportions of beef tallow or soya-bean oil and dried skim milk in the diet on growth, feed utilization, apparent digestibility and carcass composition. Br J Nutr 35:253
4. Braude R, Mitchell KG, Newport MJ, Porter JWG 1970 Artificial rearing of pigs. 1. Effect of frequency and level of feeding on performance and digestion of milk proteins. Br J Nutr 24:501

5. Braude R, Newport MJ 1973 Artificial rearing of pigs. 4. The replacement of butterfat in a whole-milk diet by either beef tallow, coconut oil or soya-bean oil. Br J Nutr 29:447

6. Braude R, Newport MJ, Porter JWG 1970 Artificial rearing of pigs. 2. The time course of milk protein digestion and proteolytic enzyme secretion in the 28-day-old pig. Br J Nutr 24:827

7. Cavell AJ 1955 The colorimetric determination of phosphorus in plant materials. J Sci Fd Agric 6:479

8. Department of Health and Social Security 1980 Report on Health and Social Subjects No. 18, Artificial Feeds for the Young Infant. London, Her Majesty's Stationary Office

9. Dodds WJ 1982 The pig model for biomedical research. Fed Proc 41:247

10. Dvorak M 1981 influence of neonatal application of testosterone on the growth of piglets. Vet Med 26:65

11. Elliott RF, Van der Noot GW, Gilbreath RL, Fisher H 1971 Effect of dietary protein level on composition changes in sow colostrum and milk. J Anim Sci 32:1128

12. Elsley FWH 1964 The physiological development of the young pig. Ann Zootech 13:75

13. Flecknell PA, Wootton R, John M, Royston JP 1981 Steady state glucose kinetics and their relation to plasma glucose concentration in the premature and full term neonatal piglet. Can J Physiol Pharm 59:1069

14. Folch J, Lees M, Stanley GHS 1957 A simple method for the isolation and purification of total lipids from animal tissues. J Biol Chem 226:497

15. Gurr MI 1981 Review of the progress of dairy science: human and artificial milks for infant feeding. J Dairy Res 48:519

16. Hambraeus L, Lonnerdal B, Forsum E, Gebre-Medhin M 1978 Nitrogen and protein components of human milk. Acta Paediatr Scand 67:561

17. Jarvenpaa AL, Raiha NCR, Rassin DK, Gaull GE 1982 Milk protein quantity and quality in the term infant. 1. Metabolic responses and effects on growth. Pediatrics 70:214

18. Marsh WH, Fingerhut B, Muller H 1965 Automated and manual direct methods for the determination of blood urea. Clin Chem 11:624

19. Natelson S, Penniall R, Crawford WL, Munsey FA 1955 Non-casein protein to casein ratio of feeding formulas-effect on blood component levels in normal infants. Am 3 Dis Child 89:656

20. Newport MJ 1979 Artificial rearing of pigs. 8. Effect of dietary protein level on performance, nitrogen retention and carcass composition. $\mathrm{Br} \mathrm{J}$ Nut 41:95

21. Newport MJ, Keal HD 1983 Artificial rearing of pigs. 13. Effect of replacement of dried skim-milk by a functional fish-protein concentrate on the performance of the pigs and digestion of protein. Br J Nutr 49:43

22. Pond WG, Barnes RH, Bradfield RB, Kwong E, Krook L 1965 Effect of dietary energy intake on protein deficiency symptoms and body composition of baby pigs fed equalized but sub-optimal amounts of protein. J Nutr 85:57

23. Pond WG, Snyder W, Snook JT, Walker EF, McNeill DA, Stillings BR 1971 Relative utilization of casein, fish protein concentrate and isolated soybean protein for growth and pancreatic enzyme regeneration of the protein-calorie malnourished baby pig. J Nutr 101:1193

24. Raiha NCR, Heinonen K, Rassin DK, Gaull GE 1976 Protein quality and quantity in low-birth-weight infants. 1. Metabolic responses and effects on growth. Pediatrics 57:659

25. Rowland SJ 1938 The determination of the nitrogen distribution in milk. J Dairy Res 9:42

26. Rowland SJ 1938 The protein distribution in normal and abnormal milk. J Dairy Res 9:47

27. Salmon-Legagneur E 1964 Nitrogen constituents of sow's milk: effect of stage of lactation and level of feeding. Ann Biol Anim Biochem Biophys 4:49

28. Schneider DL, Sarett HP 1969 Growth of baby pigs fed infant soyabean formulas. J Nutr $98: 279$

29. Schreiner RL, Brady MS, Erust JA, Lemons JA 1982 Lack of lactobezoars in infants given predominantly whey protein formulas. Am J Dis Child 136:437

30. Senterre J, Rigo J 1979 Protein requirements of low birth weight infants. In: Physiological and Biochemical Basis for Perinatal Medicine, 1st International Monset-Couchard M, Minkowski A (eds): Meeting. (Basel, Karger, pp 125132

31. Wallace WM 1959 Nitrogen content of the body and its relation to retention and loss of nitrogen. Fed Proc 18:1125

32. The authors gratefully acknowledge the technical assistance of Joyclyn A Williams.

33. Requests for reprints should be addressed to: Dr. Michael J. Newport, National Institute for Research in Dairying, Shinfield, Reading RG2 9AT, Berkshire, United Kingdom.

34. Received for publication August 17, 1983

35. Accepted for publication October 14, 1983. 